\title{
UPAYA PENERAPAN MODEL PEMBELAJARAN KOOPERATIF TIPE STUDENT TEAMS ACHIEVEMENT DIVISION DALAM MENINGKATKAN HASIL BELAJAR IPA SISWA KELAS VI SD NEGERI NO. 101794 PATUMBAK
}

\author{
Susriati \\ Guru IPA di SD Negeri No. 101794 Patumbak \\ Surel: Pasaribu6@yahoo.co.id
}

\begin{abstract}
ABSTRAK
Penelitian ini bertujuan untuk melihat aktivitas belajar siswa yang mencakup aktivitas belajar siswa saat bekerja dalam kelompok dikelas pada mata pelajaran IPA dan juga prestasi belajar siswa dengan menerapkan model pembelajaran kooperatif tipe STAD. Subjek penelitian ini diambil di kelas VI SD Negeri No. 101794 Patumbak-I dengan jumlah siswa 21 orang. Awal KBM dilakukan tes hasil belajar (Pretes), dengan data rata-rata 45,2 hal tersebut menunjukkan bahwa rata-rata siswa jarang membaca buku sebelum pembelajaran disekolah. Kemudian dilanjutkan KBM, akhir KBM ke II dan KBM ke IV dilakukan tes hasil belajar formatif I dan formatif II hasilnya masing-masing menunjukkan rata-rata 67 dan 87. Melihat data tersebut ada perubahan dan perubahan tersebut akibat tindakan guru selama KBM pada siklus II. Data aktivitas siswa menurut pengamatan pengamat pada siklus I antara lain membaca/menulis $(45 \%)$, bekerja ( $26 \%)$, bertanya sesama teman $(5,0 \%)$, bertanya kepada guru $(13,0 \%)$, dan yang tidak relevan dengan KBM (11\%). Data aktivitas siswa menurut pengamatan pada siklus II antara lain membaca/menulis $(38,5 \%)$, bekerja $(28,4 \%)$, bertanya sesama teman $(6,4 \%)$, bertanya kepada guru (16\%), dan yang tidak relevan dengan KBM (11\%). Penerapan model pembelajaran STAD selama KBM membuat siswa sangat senang, sangat antusias.
\end{abstract}

Kata Kunci : Aktivitas Belajar, STAD, IPA

\section{PENDAHULUAN}

Kualitas pendidikan, sebagai salah satu pilar pengembangan sumber daya manusia yang bermakna, sangat penting bagi pembangunan nasional. Bahkan dapat dikatakan masa depan bangsa bergantung pada keberadaan pendidikan yang berkualitas yang berlangsung di masa kini. Perkembangan teknologi tidak akan lepas dari perkembangan dalam bidang IPA. Perkembangan dari bidang IPA tidak mungkin terjadi bila tidak disertai dengan peningkatan mutu pendidikan IPA, sedangkan selama ini pelajaran IPA dianggap sebagai pelajaran yang sulit. Hal ini dapat dilihat dari Nilai mata pelajaran IPA yang rata-rata masih rendah bila dibandingkan dengan pelajaran lainnya. Ini Menunjukkan masih rendahnya mutu pelajaran IPA.

Peneliti sendiri sebagai guru kelas di kelas VI SD Negeri No. 101794 Patumbak-I memiliki masalah dalam mengajarkan mata pelajaran IPA kepada peserta didik. Tidak adanya laboratorium IPA dan kondisi perpustakaan yang kurang memadai menjadi salah satu penyebab rendahnya prestasi belajar IPA siswa. Selain fasilitas yang tidak 
mendukung, jarangnya peneliti menggunakan media pada saat mengajar juga ikut mempengaruhi rendahnya prestasi belajar siswa.

Kurangnya fasilitas dan jarangnya peneliti menggunakan media pada saat mengajar mengakibatkan rendahnya aktivitas belajar siswa. Metode konvensional yakni metode ceramah menjadi pilihan peneliti saat mengajar. Akibat penggunaan metode yang kurang mengikutsertakan siswa selama KBM mengakibatkan peneliti sering menemukan tindakan-tindakan yang tidak relevan dengan KBM selama proses KBM. Tidak jarang peneliti mendapati siswa sedang menggambar di buku tulis maupun di buku paket pada saat peneliti menjelaskan materi pembelajaran, sedangkan pemberian sanksi tidak banyak membantu.

Akibat rendahnya aktivitas belajar siswa, prestasi belajar siswa juga sangat rendah. Berdasarkan hasil ulangan semester ganjil siswa kelas VI, 40\% siswa harus mengikuti remedial untuk mata pelajaran IPA karena hasil ujian mereka yang tidak mencapai ketuntasan minimum. Kegagalan siswa di atas menjadi cambuk tajam bagi peneliti untuk memperbaiki kualitas pembelajaran yang peneliti bawakan, khususnya untuk mata pelajaran IPA. Salah satu upaya yang akan peneliti tempuh yakni dengan menerpkan model pembelajaran yang berbeda dengan metode yang biasa peneliti terapkan selama KBM.

Berdasarkan hasil diskusi peneliti dengan sesama peneliti dan juga tutor dari LPMP dan UNIMED dan pendamping peneliti dari UNIMED maka peneliti memutuskan untuk menerapkan model pembelajaran kooperatif tipe STAD.
STAD (Student Team Achivement Division) merupakan salah satu metode pembelajaran kelompok yang paling awal ditemukan. Metode ini sangat populer dikalangan para ahli pendidikan. Dalam metode STAD siswa dipasangkan secara merata yang memiliki kemampuan tinggi dan rendah dalam suatu kelompok sebanyak $4-5$ orang. Skor kelompok diberikan berdasarkan atas prestasi anggota kelompoknya. Ciriciri yang penting dalam STAD adalah bahwa siswa dihargai atas prestasi kelompok dan juga terhadap semangat kelompok untuk bekerjasama.

Berdasarkan latar belakang masalah, dapat dikaji ada beberapa permasalahan yang dirumuskan sebagai berikut :

1. Apakah model pembelajaran kooperatif tipe STAD dapat meningkatkan hasil belajar siswa pada materi pokok Ciri-Ciri Makhluk Hidup di kelas VI SD Negeri No. 101794 Patumbak-I Tahun Pembelajaran 2013/2014?

2. Apakah model pembelajaran kooperatif tipe STAD dapat meningkatkan aktivitas belajar siswa pada materi pokok CiriCiri Makhluk Hidup di kelas VI SD Negeri No. 101794 Patumbak-I Tahun Pembelajaran 2013/2014?

Merujuk pada rumusan masalah di atas, maka tujuan dilaksanakan penelitian ini adalah :

1. Untuk mengetahui apakah aktivitas belajar siswa meningkat melalui penerapan model pembelajaran kooperatif tipe STAD pada materi pokok CiriCiri Makhluk Hidup di kelas VI SD Negeri No. 101794 Patumbak-I Tahun Pembelajaran 2014/2015. 
2. Untuk mengetahui apakah prestasi belajar siswa meningkat melalui penerapan model pembelajaran kooperatif tipe STAD pada materi pokok CiriCiri Makhluk Hidup di kelas VI SD Negeri No. 101794 Patumbak-I Tahun Pembelajaran 2014/2015.

\section{METODE PENELITIAN Tempat dan Waktu Penelitian}

Penelitian ini dilakukan di SD Negeri No. 101794 Patumbak-I Jalan Pertahanan Ujung Patumbak 1 kelas IV Tahun Pelajaran 2014/2015 pelaksanaannya pada bulan September 2014 sampai dengan Desember 2014.

\section{SubjekPenelitian}

Subjek dalam penelitian ini adalah seluruh siswa kelas IV. Pemilihan kelas IV dikarenakan peneliti merupakan guru IPA di Kelas IV SD Negeri No. 101794 Patumbak-I. Banyak subjek penelitian yakni 21 orang siswa.

\section{Alat Pengumpul Data}

a) Tes hasil belajar

Tes hasil belajar digunakan untuk mengetahui hasil belajar siswa sebelum dan sesudah pembelajaran dengan model pembelajaran langsung. Tes hasil belajar disusun dalam bentuk pilihan berganda yang mengacu pada Kurikulum Tingkat Satuan Pendidikan (KTSP) untuk kelas IV SD Negeri No.101794 Patumbak-I bidang studi IPA.
Tabel Kisi-Kisi Tes Hasil Belajar

\begin{tabular}{|c|c|c|c|c|c|}
\hline \multirow{2}{*}{ Butir Soal } & \multicolumn{4}{|c|}{ Klasifikasi / } & \multirow{2}{*}{ Kumlah } \\
& \multicolumn{2}{|c|}{ Kategori } \\
\hline & $\mathrm{C}_{1}$ & $\mathrm{C}_{2}$ & $\mathrm{C}_{3}$ & $\mathrm{C}_{4}$ & \multicolumn{1}{c}{} \\
\hline 1 & & $\sqrt{ }$ & & & 1 \\
\hline 2 & & & & $\sqrt{ }$ & 1 \\
\hline 3 & & $\sqrt{ }$ & & & 1 \\
\hline 4 & & $\sqrt{ }$ & & & 1 \\
\hline 5 & & & $\sqrt{ }$ & & 1 \\
\hline 6 & & & & $\sqrt{ }$ & 1 \\
\hline 7 & & $\sqrt{ }$ & & & 1 \\
\hline 8 & & $\sqrt{ }$ & & & 1 \\
\hline 9 & $\sqrt{ }$ & & & & 1 \\
\hline 10 & & & & $\sqrt{ }$ & 1 \\
\hline Jumlah & 1 & 5 & 1 & 3 & 10 \\
\hline
\end{tabular}

\section{Rancangan Penelitian}

Desain yang digunakan dalam penelitian ini adalah desain model Kemmis dan Mc. Taggart (Dewi,2010:122). Penelitian ini dilakukan dengan 2 (dua) siklus, yaitu siklus I dan siklus II. Setiap siklus dalam penelitian ini terdiri dari 4 (empat) komponen utama yaitu: (1) Perencanaan tindakan (planning), (2) Tindakan (acting), (3) Pengamatan tindakan (observing) dan (4) Refleksi tindakan (reflect).

\section{Teknik Analisis Data}

Metode analisis data pada penelitian ini digunakan metode deskriptif dengan membandingkan hasil belajar siswa sebelum tindakan dengan hasil belajar siswa setelah tindakan.

Langkah-langkah pengolahan data sebagai berikut:

1) Merekapitulasi nilai pretes sebelum tindakan dan nilai tes akhir siklus I dan siklus II.

2) Menghitung nilai rata-rata atau persentase hasil belajar siswa sebelum dilakukan tindakan dengan hasil belajar setelah dilakukan tindakan pada siklus I dan siklus II untuk mengetahui adanya peningkatan hasil belajar. 
3) Penilaian

a. Data nilai hasil belajar (kognitif) diperoleh dengan menggunakan rumus:

Nilai Siswa $=\frac{\text { Jumlah jawaban benar }}{\text { Jumlah seluruh soal }} \times 100$

(Slameto,2001:189)

b. Nilai rata-rata siswa dicari dengan rumus sebagai berikut:

$$
\bar{X}=\frac{\sum X}{N}
$$

(Subino,1987:80)

Keterangan :

$\bar{X}=$ Nilai rata-rata

$\Sigma=$ Jumlah nilai $X$

$\mathrm{N}=$ Jumlah peserta tes

c. Untuk penilaian aktivitas digunakan rumus sebagai berikut:

Setelah data aktivitas siswa terkumpul sesuai dengan jumlah kegiatan belajar mengajar, maka data tersebut disusun kemudian data tersebut dirubah menjadi data prosntase. Untuk menganalisis data-data tersebut kemudian dianalisis dengan proporsi aktivitas.

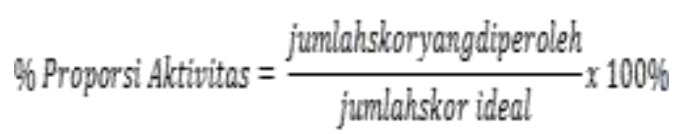

(Majid, 2009:268)

d. Ketentuan persentase ketuntasan belajar kelas
Ketuntasan belajar kelas $=\frac{\sum S_{b}}{K} \times 100 \%$ $\Sigma \mathrm{Sb}=$ Jumlah siswa yang mendapat nilai $\geq$ 70 (kognitif)

$\Sigma \mathrm{K}=$ Jumlah siswa dalam sampel

Sebagai tolak ukur keberhasilan penelitian tindakan kelas ini dapat dilihat dari hasil tes, jika hasil belajar siswa mencapai nilai $\geq 70$ maka disebut tuntas individu, dan bila ada $85 \%$ nilai $\geq$ 70 disebut tuntas kelas.

\section{HASIL PENELITIAN DAN PEMBAHASAN \\ Gambaran Awal Penelitian}

Sebelum melaksanakan siklus I maka terlebih dahulu peneliti mengumpulkan data untuk melihat kondisi siswa sebelum dilakukan penelitian. Adapun pengumpulan data yakni dengan memberikan uji pretes kepada siswa. Data yang diperoleh yakni tidak seorangpun siswa mendapat nilai di atas KKM 70, dengan ketuntasan klasikal 0\% dan rata-rata nilai 45,2. Hal ini menunjukkan bahwa siswa tidak pernah mempersiapkan diri sebelum mengikuti pembelajaran dan rendahnya aktivitas belajar siswa di rumah.

\section{Siklus I}

Pada Siklus I peneliti melakukan proses pembelajaran dan pengamatan terhadap proses pembelajaran tersebut. Pengamatan terhadap data proses dilakukan sesuai dengan indikator keberhasilan proses yang telah ditetapkan dalam perencanaan. Data yang muncul dalam pelaksanaan tindakan kemudian diamati dan dipaparkan. Data proses 
yang diamati pada penelitian tindakan kelas ini meliputi :

(1) data mengenai ketepatan prosedur pelaksanaan tindakan yang dilakukan guru atau peneliti,

(2) data mengenai keaktifan anak.

Siklus pertama terdiri dari empat tahap, yakni perencanaan, pelaksanaan, pengamatan, dan refleksi, seperti berikut ini :

\section{Perencanaan}

Pada tahap ini peneliti membuat kegiatan perencanaan meliputi:

a) Penyusunan rencana pelaksanaan pembelajaran (RPP).

b) Membuat lembar kegiatan siswa pertemuan 1 dan pertemuan 2 .

c) Membuat tes pemahaman siswa siklus I.

d) Membuat lembar observasi aktivitas siswa.

e) Menyediakan media pembelajaran.

\section{Pelaksanaan}

Melaksanakan tindakan pembelajaran ke-1 dan ke-2 sesuai dengan RPP oleh peneliti sebagai guru Matematika di SD Negeri No. 101794 Patumbak-I. Selama proses pembelajaran dilakukan observasi oleh observer (guru sejawat) untuk mengamati aktivitas siswa dan pengelolaan pembelajaran oleh guru. Diakhir siklus I dilakukan pula tes hasil belajar siswa untuk mengetahui pemahaman siswa dengan meggunakan tes hasil belajar sebagai formatif I.

Tabel Hasil Formatif I

\begin{tabular}{|c|c|c|c|c|}
\hline Nilai & Frekuensi & $\begin{array}{c}\text { Tuntas } \\
\text { Individu }\end{array}$ & $\begin{array}{c}\text { Tuntas } \\
\text { Kelas }\end{array}$ & $\begin{array}{c}\text { Nilai } \\
\text { rata- } \\
\text { rata }\end{array}$ \\
\hline 50 & 4 & - & - & \multirow{2}{*}{6} \\
\cline { 1 - 4 } 60 & 7 & - & - & \multirow{2}{*}{67} \\
\hline 80 & 10 & 10 & $47,61 \%$ & \\
\cline { 1 - 3 } Jumlah & 21 & 10 & $47,61 \%$ & \\
\hline
\end{tabular}

Pada tabel 1 diatas, nilai terendah formatif I adalah 50 sebanyak 4 orang dan nilai tertinggi adalah 80 sebanyak 10 orang, dengan 11 orang mendapat nilai dibawah kriteria ketuntasan atau ketuntasan klasikal adalah sebesar 47,61\%. Dengan nilai KMM sebesar 70 nilai ini berada sedikit di bawah kriteria keberhasilan klasikal sehingga dapat dikatakan KBM siklus I kurang berhasil memberi ketuntasan belajar dalam kelas. Nilai rata-rata kelas adalah 67 belum tuntas KKM.

\section{Pengamatan}

Selama proses pembelajaran yang dilakukan oleh peneliti, peneliti berkolaborasi degan 2 orang teman sejawat (Pengamat/observer) untuk mengamati kegiatan siswa. Kegiatan siswa diamati selama 20 menit dengan menggunakan lembar aktivitas siswa yang sudah dipersiapkan sebelumnya. Pengamat mengamati aktivitas siswa dengan cara menceklis setiap dua menit sekali. Kelompok yang diamati adalah kelompok yang sebelumnya sudah ditentukan oleh peneliti dan pengamat. Hasil pengamatan observer pada siklus I seperti pada tabel 2 berikut :

Tabel Hasil pengamatan observer pada siklus I

\begin{tabular}{|c|c|c|c|c|}
\hline \multicolumn{5}{|c|}{ Siklus I } \\
\hline No & Aktivitas & $\mathrm{Jlh}$ & $\begin{array}{l}\text { Rata- } \\
\text { Rata }\end{array}$ & Persentase \\
\hline 1 & Menulis,membaca & 45 & 11,25 & $45 \%$ \\
\hline 2 & Mengerjakan & 26 & 6,5 & $26 \%$ \\
\hline 3 & $\begin{array}{l}\text { Bertanya pada } \\
\text { teman }\end{array}$ & 5 & 1.25 & $5,0 \%$ \\
\hline 4 & $\begin{array}{l}\text { Bertanya pada } \\
\text { guru }\end{array}$ & 13 & 3,25 & $13,0 \%$ \\
\hline 5 & Yang tidak relevan & 11 & 2,75 & $11 \%$ \\
\hline & Jumlah & 100 & 25 & $100 \%$ \\
\hline
\end{tabular}




\section{Refleksi}

Berdasarkan hasil observasi KBM pada siklus I, masih terdapat beberapa kekurangan selama KBM siklus I, diantaranya yaitu:

1. Diskusi tidak terlaksana secara maksimal, karena beberapa siswa tidak aktif dalam melaksanakan diskusi, siswa tersebut hanya berdiam diri, seolah-olah tidak mau tahu dan hanya melakukan kegiatan menulis dan membaca, meskipun ada beberapa siswa yang aktif dalam berargumen.

2. Keaktifan siswa belum maksimal. Kemungkinan besar penyebabnya waktu yang terlalu singkat untuk melakukan praktikum dan penyelesaian LKS, sehingga terkesan terburuburu.

3. Waktu yang tersedia hanya 2 jam pelajaran untuk melakukan KBM (termasuk untuk praktikum dan presentasinya) maka terkesan terburu - buru untuk menyelesaikannya.

4. Pembahasan lebih didominasi oleh satu atau dua orang sedangkan anggota lain hanya mengikuti saja. siswa kurang dalam mengajukan pertanyaan atau pendapat pada presentasi yang telah dilakukan kelompok lain.

Upaya-upaya yang dilakukan untuk memperbaiki kelemahan yang terjadi pada siklus I akan diterapkan pada KBM siklus II adalah antara lain:

1) Peneliti menginformasikan bahwa di akhir pertemuan siklus II akan ada tes formatif, dengan harapan agar siswa lebih aktif dalam belajar.

2) Peneliti menegaskan pada siswa bahwa siswa yang tidak serius dalam pelaksanaan diskusi, dan siswa yang mengganggu temannya akan dihukum oleh guru.

3) Peneliti menjanjikan hadiah bagi kelompok terbaik, dengan harapan setiap kelompok akan melakukan yang terbaik karena janji peneliti.

4) Peneliti lebih memperhatikan kelompok-kelompok yang kurang aktivitas belajarnya agar kelompok tersebut menjadi lebih aktif, peneliti juga selalu berupaya membuat setiap kelompok untuk ingin tau terus menerus dengan mengajukan pertanyaan dan memberi deskripsi percobaan sehingga siswa menjadi menjadi lebih aktif.

\section{Siklus II}

Sama halnya dengan Siklus I, pada Siklus II peneliti (guru) melakukan tahap-tahap proses pembelajaran, yaitu perencanaan, pelaksanaan, pengamatan, dan refleksi. Tahap-tahap pembelajaran di atas akan dirincikan di bawah ini:

\section{Perencanaan}

Hal-hal yang dilakukan dalam perencanaan adalah :

a. Menyiapkan Silabus II dan RPP untuk pertemuan 3 dan pertemuan 4.

b. Menyiapkan Materi Pelajaran.

c. Menyiapkan Lembar Kerja Siswa (LKS 2 dan LKS 3).

d. Menyiapkan Lembar Aktivitas Siswa.

e. Menyiapkan soal tes hasil belajar siklus II (Formatif II).

f. Memperhatikan refleksi pada siklus I. 


\section{Pelaksanaan}

Sebelum

kegiatan

pembelajaran berlangsung dengan menggunakan model pembelajaran kooperatif tipe STAD, peneliti mempersiapkan diri agar penelitian berlangsung lebih baik. Pada tahap ini peneliti melaksanakan kegiatan yang telah disusun dan memberikan formatif II.

Tabel Hasil Formatif II

\begin{tabular}{|c|c|c|c|c|}
\hline Nilai & $\begin{array}{c}\text { Frekue } \\
\text { nsi }\end{array}$ & $\begin{array}{c}\text { Tuntas } \\
\text { Individu }\end{array}$ & $\begin{array}{c}\text { Tuntas } \\
\text { Kelas }\end{array}$ & $\begin{array}{c}\text { Rata } \\
\text {-rata }\end{array}$ \\
\hline 60 & 2 & - & - & \multirow{2}{*}{8} \\
\cline { 1 - 4 } 80 & 10 & 10 & $47,6 \%$ & \multirow{2}{*}{8} \\
\cline { 1 - 4 } 100 & 9 & 9 & $42,8 \%$ & \\
\cline { 1 - 4 } Jumlah & 21 & 19 & $90,45 \%$ & \\
\hline
\end{tabular}

Merujuk pada tabel 3, nilai terendah untuk Formatif II adalah 60 sebanyak 2 orang dan tertinggi adalah 100 sebanyak 9 orang. Dengan 2 orang mendapat nilai dibawah kriteria ketuntasan atau ketuntasan klasikal adalah sebesar $90,45 \%$. Nilai ini berada di atas kriteria keberhasilan sehingga dapat dikatakan KBM Siklus II berhasil memberi ketuntasan belajar dalam kelas. Nilai rata-rata kelas adalah 87.

\section{Pengamatan}

Pengamatan dimulai dengan memperhatikan proses pembelajaran dari pembuka, kegiatan inti dan kegiatan penutup. Peneliti melakukan observasi dibantu dengan observer dengan terlebih dahulu mempersiapkan lembar observasi aktivitas belajar. Dari observasi yang telah dilakukan, maka diperoleh beberapa perihal yang dilakukan anak pada saat kegiatan pembelajaran berlangsung, antara lain:

\begin{tabular}{|c|l|c|c|c|}
\hline \multicolumn{5}{|c|}{ Siklus II } \\
\hline No & \multicolumn{1}{|c|}{ Aktivitas } & Jlh & $\begin{array}{c}\text { Rata- } \\
\text { Rata }\end{array}$ & Persentase \\
\hline 1 & Menulis,membaca & 42 & 10,5 & $38,5 \%$ \\
\hline 2 & Mengerjakan & 31 & 7,75 & $28,4 \%$ \\
\hline 3 & $\begin{array}{l}\text { Bertanya pada } \\
\text { teman }\end{array}$ & 7 & 1,75 & $6,4 \%$ \\
\hline 4 & $\begin{array}{l}\text { Bertanya pada } \\
\text { guru }\end{array}$ & 17 & 4,25 & $16 \%$ \\
\hline 5 & Yang tidak relevan & 12 & 3 & $11,0 \%$ \\
\hline & Jumlah & 100 & 27,25 & $100 \%$ \\
\hline
\end{tabular}

\section{Refleksi}

Selama pengamatan terhadap kegiatan siswa siklus II (ranah afektif), penilaian terhadap tes hasil belajar (ranah kognitif), dan pengamatan terhadap pelaksanaan penerapan model pembelajaran Langsung siklus II, sudah tidak terlihat hal-hal yang harus diadakan perbaikan, siswa yang belum terkendali pada pertemuan pembelajaran sebelumnya tidak menjadi bagian yang menggangu pembelajaran, pada siklus II dapat diatasi oleh Peneliti dengan baik, hasil belajar siswa sudah menunjukkan peningkatan dan semua siswa dikatakan tuntas. Secara keseluruhan semua aspek dalam hasil belajar mengalami peningkatan dari siklus I ke siklus II. Karena proses pelaksanaan pada siklus I dan siklus II telah dapat mencapai hasil dari pembelajaran yang diharapkan dan telah dapat menjawab rumusan masalah pada penelitian ini, maka tindakan pembelajaran pada siklus III tidak dilanjutkan lagi.

\section{Pembahasan Penelitian}

Data hasil penelitian yang telah tersaji pada tabel 1, 2, 3 dan 4. Dari data tabel tersebut diatas 1 dan 3 terjadi peningkatan aktivitas belajar siswa. pada siklus I aktivitas belajar siswa sebagai berikut: aktivitas menulis dan membaca $45 \%$, aktivitas 
mengerjakan LKS 26\%, aktivitas bertanya pada teman $5,0 \%$, aktivitas bertanya pada guru $13,0 \%$, aktivitas yang tidak relevan dengan KBM $11 \%$. Pada siklus II, aktivitas menulis dan membaca turun menjadi $38,5 \%$ yang mengindikasikan siswa sudah mempersiapkan diri dari rumah sehingga siswa tidak lagi perlu banyak membaca di sekolah pada saat pelaksanaan diskusi, hal ini juga mengindikasikan turunnya tindakan individual siswa. Aktivitas mengerjakan LKS pada siklus II mengalami peningkatan yakni dari $26 \%$ menjadi 28,4\%. Hal ini menunjukkan bahwa siswa menjadi lebih aktif dalam mengerjakan LKS. aktivitas bertanya kepada teman mengalami peningkatan menjadi $6,4 \%$, hal ini menunjukkan siswa menjadi lebih kooperatif dan lebih bekerjasama dengan temannya, sehingga aktivitas bertanya meningkat. Aktivitas bertanya pada guru mengalami peningkatan hal ini mengindikasikan siswa sudah lebih mandiri dalam berpikir sehingga berkurang ketergantungannya pada guru. Aktivitas yang tidak relevan tetap pada persentasenya yaitu $11 \%$. Seluruh data aktivitas di atas menunjukkan bahwa aktivitas belajar siswa menjadi lebih baik dari siklus I ke siklus II.

Memang harus diakui, bahwa dengan model pembelajaran kooperatif seperti yang diterapkan siswa sepertinya merasakan adanya suasana belajar yang menyenangkan (joyful learning atau learning is fun). Hal ini setidaknya terbukti dari data hasil belajar atau prestasi belajar siswa sebagaimana tersajikan pada tabel 4.1 dan Tabel 4.3 di atas dengan jelas membuktikan bahwa telah terjadi peningkatan yang sangat signifikan pada prestasi belajar siswa, dari semula hanya 10 siswa atau sebesar $47,61 \%$ yang tuntas belajar pada siklus I meningkat menjadi 19 siswa atau sebesar 90,45\% pada akhir siklus II, yang berarti mengalami peningkatan sebesar $42,84 \%$ untuk kategori ini. Sementara itu untuk kategori penilaian hasil yang lain, yakni kategori siswa yang tidak tuntas, dari semula sebanyak 11 siswa $(52,38 \%)$ yang tidak tuntas pada siklus I berkurang secara drastis menjadi hanya 2 siswa $(9,52 \%)$ yang tidak tuntas pada akhir siklus II, yang berarti berkurang sebesar $42,86 \%$.

Bila dilihat dari segi kriteria keberhasilan secara klasikal yang telah ditetapkan, yakni sebesar $85 \%$ dari seluruh siswa dalam kelas harus mencapai ketuntasan belajar, sementara dari penilaian hasil di akhir siklus II ini hanya menyisakan $10 \%$ yang tidak tuntas (yang berarti 90\% siswa telah mencapai ketuntasan belajar), maka dari situ dapat dipahami lebih jauh bahwa tindakan guru melalui penerapan pembelajaran kooperatif tipe STAD ini telah berhasil mencapai tujuannya.

STAD didesain untuk meningkatkan rasa tanggung jawab siswa terhadap pembelajarannya sendiri dan juga pembelajaran orang lain. Siswa tidak hanya mempelajari materi yang diberikan, tetapi mereka juga harus siap memberikan dan mengajarkan materi tersebut pada anggota kelompoknya yang lain. Dengan demikian, "siswa saling tergantung satu dengan yang lain dan harus bekerja sama secara kooperatif untuk mempelajari materi yang ditugaskan". 


\section{KESIMPULAN}

Data-data tes hasil belajar, aktivitas belajar siswa, dan minat siswa terhadap model pembelajaran kooperatif Tipe STAD selama kegiatan belajar mengajar, kemudian dianalisis, sehingga dapat disimpulkan sesuai dengan rumusan masalah.

1. Data aktivitas siswa menurut kedua pengamatan pengamat pada Siklus I antara lain: menulis/membaca (45\%), bekerja $(26 \%)$, bertanya sesama teman $(5,0 \%)$, bertanya kepada guru $(13,0 \%)$, dan yang tidak relevan dengan KBM (11\%). Dan Data aktivitas siswa menurut pengamatan pada Siklus II antara lain: menulis/membaca $(38,5 \%)$, bekerja $(28,4 \%)$, bertanya sesama teman $(6,4 \%)$, bertanya kepada guru (16\%), dan yang tidak relevan dengan KBM $(11,0 \%)$.

2. Dengan menerapkan model pembelajaran kooperatif Tipe STAD prestasi belajar siswa dari Siklus ke Siklus berikutnya mengalami peningkatan. Hasil belajar siswa pada Formatif I dan Formatif II menunjukkan 10 orang siswa tuntas secara individu, sedangkan kelas tidak tuntas. Pada Siklus II, tuntas secara individu sebanyak 19 orang siswa, sedangkan kelas adalah tuntas dengan rata-rata siklus I dan siklus II adalah 67 dan 87.

Dengan demikian maka tindakan guru dalam menerapkan model pembelajaran kooperatif tipe STAD pada bidang studi IPA di sini telah berhasil mencapai tujuan yang diinginkan.

Dari hasil yang diperoleh dalam penelitian ini, maka ada beberapa saran yang diajukan yaitu:
1. Untuk menerapkan model pembelajaran STAD maka guru harus pandai memanajemen waktu sebaik mungkin, agar tidak terkesan terburu-buru.

2. Kepada siswa, para siswa hendaknya lebih meningkatkan kerjasamanya dalam kegiatan pembelajaran, terutama dalam mengerjakan tugas-tugas kelompok yang diberikan oleh guru.

3. Kepada teman sejawat, guru; jika menghadapi masalah pembelajaran yang sama atau yang mirip dengan masalah yang ada dalam penelitian ini, kiranya patut dicoba untuk diatasi dengan menerapkan model pembelajaran kooperatif tipe STAD, pada bidang studi yang sama dengan ini ataupun untuk bidang studi yang lain. Mengingat satu dan lain hal, model pembelajaran kooperatif tipe STAD selain prosedurnya mudah dan sederhana, dampaknya sangat terasa bagi peningkatan aktivitas belajar siswa sesuai dengan tuntutan dan trend pembelajaran yang berkembang akhir-akhir ini.Kerjasama dengan rumpun bidang studi lain untuk bertukar pikiran tentang pengembangan model pembelajaran inovatif.

\section{DAFTAR RUJUKAN}

Arikunto, Suharsimi. 2002. DasarDasar Evaluasi Pendidikan. Jakarta: Bumi Aksara.

Arikunto, Suharsimi. 2002. Prosedur Penelitian Suatu Pendekatan Praktek. Jakarta: Rineksa Cipta.

Departemen Pendidikan dan Kebudayaan. 1994. Petunjuk Pelaksanaan 
Proses Belajar Mengajar. Jakarta: Balai Pustaka.

Djamarah, Syaiful Bahri. 2002. Strategi Belajar Mengajar. Jakarta: Rineksa Cipta.

Hamalik, Oemar. 1994. Metode Pendidikan. Bandung: Citra Aditya Bakti.

Joyce, Wheil, dan Calhoun. (2010). Model's of Teaching (Model - Model Pengajaran. Yogyakarta: Pustaka Pelajar.

Kemmis, S. dan Mc. Taggart, R. 1988. The Action Research Planner. Victoria Dearcin University Press.

Margono. $1997 . \quad M e t o d o l o g i$ Penelitian Pendidikan. Jakarta: Rineksa Cipta.

Mochtar Buchari. 1986. DasarDasar Kependidikan. Bandung: Tarsito.

Muhibbinsyah. 2010. Psikologi Pendidikan. Bandung: PT.Remaja Rosdakarya.

Nur, Moh. 2001. Pemotivasian Siswa untuk Belajar. Surabaya. University Press. Universitas Negeri Surabaya.

Sanjaya M.Pd, Dr.Wina. 2009. Strategi Pembelajaran Berorientasi Standar Proses Pendidikan. Jakarta: Kencana.

Slameto. (2003). Belajar dan FaktorFaktor yang Mempengaruhinya. Rineka Cipta. Jakarta.

Sudjana, Dr.Nana. 1998. DasarDasar Proses Belajar Mengajar. Bandung: Sinar baru Algensindo.

Sumadi Suryabrata.1993.Psikologi Pendidikan. Jakarta: Raja Grafindo Persada.
Susriati. 2014. Meningkatkan Aktivitas Belajar Siswa Melalui Model Pembelajaran Kooperatif Tipe Student Teams Achievemnt Division (STAD) Pada Mata Pelajaran IPA di Kelas IV SDN 101794 Patumbak-I T.A 2014/2015. 